\title{
Ethics and Education
}

\section{Should teachers be authentic?}

\section{Lauren Bialystok}

To cite this article: Lauren Bialystok (2015): Should teachers be authentic?, Ethics and Education, DOI: 10.1080/17449642.2015.1099801

To link to this article: http://dx.doi.org/10.1080/17449642.2015.1099801

曲 Published online: 19 Nov 2015.

Submit your article to this journal

Џ Article views: 4

Q View related articles $\square$

View Crossmark data ¿ 


\title{
Should teachers be authentic?
}

\author{
Lauren Bialystok* \\ Ontario Institute for Studies in Education, University of Toronto, Toronto, Canada.
}

\begin{abstract}
Authenticity is often touted as an important virtue for teachers. But what do we mean when we say that a teacher ought to be 'authentic'? Research shows that discussions of teacher authenticity frequently refer to other character traits or simply to teacher effectiveness, but authenticity is a unique concept with a long philosophical history. Once we understand authenticity as an ethical and metaphysical question, the presumed connection between authenticity and teaching appears less solid. While being true to oneself may render it more likely that a teacher does her job well, there is also reason to believe that excellent teachers can be inauthentic and that inept or even very dangerous teachers can be authentic. This paper breaks down the concept of teacher authenticity and examines three cases to show that the relationship between authenticity and good teaching is less direct that it may initially seem.
\end{abstract}

Keywords: authenticity; teaching; sincerity; identity; selfhood

Authenticity has become a highly fashionable subject in education, and in particular, it has become accepted that teachers ought to strive for authenticity (Palmer 1998; Cranton 2001; Chickering, Dalton, and Stamm 2006; Kreber and Klampfleitner 2012). In fact, across much literature, being authentic is sometimes conflated with being a good teacher simpliciter. But why should teachers be authentic? We are not in a position to answer this question until we have a deeper understanding of the concept of authenticity in personal identity and how it may apply to a specific profession. Authenticity is an idea with complex philosophical roots that lies on the border of metaphysics and ethics, posing challenging questions about both who we are and who we ought to be. Although discussions of such questions occasionally arise in the education literature, they are highly eclectic and rarely appeal to a systematic philosophical understanding of either selfhood or authenticity. ${ }^{1}$ Moreover, it is not clear that we can leap from a generic discussion of personal authenticity to the relevance of this ideal for teachers in particular. In this paper, I suggest how we may understand the concept of an authentic teacher, and also cast doubt on the de facto assumption that teachers are better if they are authentic. ${ }^{2}$ I begin by offering some general comments about the idea of authenticity and separating it from neighboring concepts with which it is frequently conflated. Second, I give a prima facie account of what it might mean to say that a teacher is authentic. Third, I compare this account with those available in the educational literature. Finally, I problematize the presumption that teachers should be authentic by way of three examples.

\footnotetext{
*Email: lauren.bialystok@utoronto.ca
} 


\section{What is authenticity?}

Authenticity is a description of identity. Something that is authentic, is aligned in its identity; it is self-identical; it is what it says it is. ${ }^{3}$ A pearl is authentic if it comes from an oyster, therefore, and a painting is authentic if it was in fact painted by the artist presumed responsible for it. To put it differently, the essential property of a pearl is that it comes from an oyster, and the essential property of a Van Gogh is that it was painted by Van Gogh. While this task of naming criteria for identity is not difficult for inanimate objects, it becomes much thornier when we seek to describe the authentic self. To be coherent, being an authentic person would have to mean 'being myself' in some way while imagining that it is possible for me to not 'be myself.' If we can't be inauthentic, it is pointless to trumpet the value of being authentic. While we may have vague ideas about the differences here, when we subject our experience of personal identity to philosophical scrutiny, we find no bright lines. Is the authentic self that self which I am most of the time? What, then, if I am inauthentic most of the time? Is it authentic to follow my strongest desires and impulses? Why should I assume these do not mask more authentic feelings underneath? Am I authentic to the extent that I differentiate myself from others? Why is it not possible that my true self is very similar to others'? If I substantially change my career, political convictions, or faith during my adult life, have I gone from inauthentic to authentic? How would I know? These are just a few of the vexing questions that would need to be sorted out to present any reliable criteria for personal authenticity.

Some of these puzzles about personal identity are taken up in recent analytic philosophical literature (e.g. Frankfurt 1988; Guignon 2004; Velleman 2006; Cottingham 2010). However, much philosophical thought has interpreted authenticity in a different vein: rather than being who I already am, being authentic entails creating the self I want to be. To various extents, this anti-essentialist notion of authenticity is defended by existentialists such as Nietzsche, Sartre, and Heidegger. This 'constructionist' (Varga 2012) or 'expressivist' (Degenhardt 2003) model suggests that the truth about myself to which I ought to be authentic is a kind of freedom or creative potential, rather than a pre-existing identity. To be authentic then becomes a question of fashioning myself according to personally chosen ideals. Even so, such a conception requires a notion of who I am and a method for distinguishing between authentic and inauthentic versions of myself; otherwise, how can I know that I am creating myself in an authentic manner, and not in conformity to someone else's ideals? ${ }^{4}$ Furthermore, an argument needs to be made for why it is better to 'make oneself' than to be 'who one already is,' if these are in tension.

Another category of accounts of personal authenticity focus, not on the characteristics of the self that strives to be achieved or discovered, but on the moral connectedness between the self and the social world through which it comes into being. Charles Taylor's influential account of authenticity in The Ethics of Authenticity defends such a position and, notably, is widely referred to by educational theorists (e.g. Grimmett and Neufeld 1994; Splitter 2009; Kreber 2013). The metaphysics required here are, however, left deliberately scant, as Taylor's primary objective is to rescue the value of authenticity from a culture of narcissism and relativism that authorizes the individual to do anything she wants in the name of self-actualization. Hence, he argues that '[a]uthenticity is not the enemy of demands that emanate from beyond the self; it supposes such demands,' (Taylor 1991, 41) and he cites ways in which self-actualization can occur in the context of self-transcending goods, or 'horizons of significance.' Even if authenticity can coalesce seamlessly with independently virtuous acts ${ }^{5}$ in this manner, Taylor de-emphasizes 
the questions about identity that become significant when we seek to apply authenticity to a given person. For example, we must consider why I choose the particular horizons of significance I do - what it is about myself that stands to be authenticated in such a way - as well as the pesky counterexample, familiar to philosophers of identity, that the 'true self' within me might just be a villain (Williams 2002). ${ }^{6}$

In short, regardless of the philosophical tradition invoked, the metaphysics and ethics of selfhood are inescapable precursors to a meaningful conversation about authenticity. This is at least as true in education and other applied fields where authenticity is used as it is in 'pure' philosophy. The point that I wish to stress is that attributing the adjective 'authentic' to a person automatically provokes philosophical questions in a way that qualifying other types of things does not. It is not satisfying, from a philosophical perspective, to simply declare that I am my 'true self,' or that I could even isolate such an entity in principle. Nor is there anything embedded within the concept of authenticity to guarantee that being one's true self will automatically have salutary effects, educational or otherwise.

An example will help illustrate the difficulty of pinpointing the authentic self, and begin to map questions of authenticity onto questions of good teaching. Carolin Kreber, a British professor who has done extensive research on authenticity in teaching, describes coming out as a lesbian to her academic colleagues as an act of authenticity that was also necessary to her teaching (Kreber 2010a). Living in accordance with felt one's sexual orientation is a good paradigmatic example of authenticity. ${ }^{7}$ Everyone has a sexual identity - even if it is neither binary nor stagnant - and to repress it can only be construed as being untrue to oneself, that is, being inauthentic. Being 'in the closet' as a gay or lesbian often involves tremendous suffering, perhaps because it requires a certain fracturing of one's identity. Before coming out, Kreber described her existence as involving 'a great deal of self-deception' (Kreber 2010a, 181). Hence, dropping the façade of presumed heterosexuality enabled her to honest be with herself by eliminating constructed divisions in her psyche.

But coming out is also an act of truth-telling to others. This phenomenon is better described as sincerity than as authenticity - a distinction made most famously by Lionel Trilling - and poses different, albeit related, questions (Trilling 1972). A person could in principle be sincere in the sense of honest to others while being inauthentic in the sense of dishonest with herself, and vice versa (Bialystok 2011). Authenticity is supposed to involve being 'true to oneself,' often in spite of what this means for one's relations with others; relationality alone is an inadequate gauge of authenticity. ${ }^{8}$ So, was Kreber being true to herself by coming out? Was she living the most essential or truest version of herself by telling others that she was a lesbian? This seems to depend on further facts about herself, beyond just being a lesbian, such as her goals and values. To what extent does she need to share her personal life with colleagues or students to feel like herself? ${ }^{9}$

Note that the value of authenticity is taken for granted here as in most contexts. Yet, it is uncertain whether coming out was necessarily a virtuous act for Kreber; as she points out, "there are many circumstances where "coming out" ... is not possible ... or could have severe consequences' - for instance, if she worked in a homophobic environment (Kreber 2010a, 186). In such cases, it would seem unfair to exhort people to be authentic, or to judge them for failing to be. Authenticity may be a virtue, but not necessarily a master virtue that trumps all others when they conflict. Furthermore, although Kreber works in education and actually studies authenticity in teaching, it is not at all clear whether, or how, her coming out at work made her a better or a more 'authentic' teacher, even if it contributed to her self-fulfillment. As Buchmann argues, 
'self-realization in teaching is not a good in itself, but only insofar as pursuing self-realization leads to appropriate student learning' (1993, 154). Much clearer lines would have to be drawn between effective teaching and openness about sexual orientation before we could conclude that this particular act of authenticity promoted good teaching - the latter being a difficult phenomenon to measure at the best of times.

Despite competing conceptions of what it means to be an authentic individual, then, we can see that authenticity is at the very least conceptually distinct from sincerity, consistency, and simply being a good person. Rather, authenticity refers to a thick notion of the 'true self.' To be authentic is to live in alignment with whatever is most essential in one's identity - to be, as it were, the 'most me' I could be. There will be no guaranteed method of verifying what that is, but in some cases, we can at least make comparative judgments: this is more essential to me than that, or I feel more comfortable with myself here than I do there. Such distinctions will only be discernible, if at all, to the subject in question.

The idea of authenticity so described does not have any obvious relationship to being a good teacher. The claim that teachers ought to be authentic needs to make a convincing link between the notion of authenticity proper and the role of being a teacher. What might this argument look like?

\section{How is authenticity relevant to teaching?}

For several decades, authenticity has been touted as an essential ingredient of good education: contemporary educators are expected to develop authentic learning environments, authentic assessments, and authentic pedagogy, not to mention cultivate authenticity in their students (Bonnett 1978; Martel 1989; Newmann, Marks, and Gamoran 1996; Palmer 1998; Splitter 2009; Ashton 2010; Kreber 2013). ${ }^{10}$ However, none of these applications of authenticity to education logically requires that the teacher involved be an authentic one.

This oversight could have to do with ambiguity about the very meaning of being an authentic teacher. We have seen that it is already difficult to explain what it means to be an authentic individual of any description. How, then, can we grasp what it means to be authentic qua teacher? There are at least three definitions that will undoubtedly set us on the wrong path. First, an authentic teacher is not - or not only - a 'real' teacher in the way that an authentic pearl is a 'real' pearl. If we judge the reality of teachers by some empirical measurement, such as board-recognized certification, then virtually all teachers in the formal education system are automatically authentic. While being properly trained and certified as a teacher may be a pre-requisite for further types of authenticity, this is too shallow a definition. It renders the question of who may be an authentic teacher philosophically uninteresting.

Second, an authentic teacher cannot be, as is sometimes claimed, a teacher who practices 'authentic pedagogy' or employs 'authentic assessment,' whatever those activities may mean. ${ }^{11}$ These, too, say little or nothing about the teacher's own identity and her relationship to herself. Painting his own paintings did not make Van Gogh an authentic person, or necessarily an authentic painter. It only made his paintings authentic Van Goghs.

This is a critical point. The notion that authentic teachers automatically practice certain types of pedagogy, or that by defining authentic pedagogy we can mutato mutandis arrive at an understanding of teacher authenticity, pervades the literature. Such assumptions are also clearly bound up with the general belief that authenticity and 'good' 
teaching mutually imply each other. Authentic teaching and teacher authenticity have been thought to be evidenced by constructivist developmental pedagogy (Kreber 2010b), by being transparent about academic expectations (Brookfield 2006, 8), by caring about students (Frego 2006), and by everything from class debates to writing poetry (Kreber 2013, 56-60). ${ }^{12}$ While these may all be valuable practices, they tell us precious little about the identity of the teacher. If authenticity is a possible mode of selfhood, then we may not infer the status of a teacher's authenticity from the methods that happen to be on display in his classroom.

Third, an authentic teacher should not be understood as an authentic person who coincidentally earns his livelihood as a teacher. While closer to meeting the thrust of authenticity as I have portrayed it, this definition still fails to explain what it is about teaching that is authentic for any particular individual. Is it not more informative than saying that one is an authentic plumber, simply because one is a plumber who happens to be generally authentic. Similarly, the fact that Kreber's coming out at work may be viewed as an act of authenticity does not say anything specific about her authenticity vis-à-vis the type of educational work that she happens to do. By hypothesis, she could have been equally authentic had she come out in a completely different work environment.

The remaining alternative, and the one that is (unsurprisingly) the most elusive in practical terms, is that the authentic teacher is a teacher for whom teaching is essentially related to her true self. An authentic teacher is an authentic person whose identity is expressed or confirmed in some necessary way through her teaching. ${ }^{13}$ For such a person, not teaching may be inauthentic. In the final section, I will review three examples of what this relationship between self and teaching may look like.

With this working understanding of how we can meaningfully describe a teacher as authentic, we can return to the normative question. Why should a teacher be authentic? Does having a certain type of relationship with oneself result in better teaching? We may think there is an ethical link here for two reasons.

First, we may think that an authentic individual who feels that teaching is part of her identity may be more disposed to take her work seriously, take pride in her role, and enjoy being a teacher. ${ }^{14}$ This in turn may lead to more effective teaching, although the particular methods involved would vary. Note that this link between authenticity and professional performance is not unique to teaching; it would likewise explain why it is preferable for a plumber to be an authentic plumber, or for an accountant to be an authentic accountant. However, insofar as we think, teachers have a special responsibility to do their jobs well; it might be salient to stress authenticity among teachers in particular.

The second reason we may think an authentic teacher is a better teacher is that an authentic individual may be more likely to model or cultivate similar virtues in others. Specifically, a teacher who has wrestled with her own identity and strives to be 'true to herself' may be in a stronger position to help students 'find' and accept their own identities. Although this may not translate into better classroom performance, it may be regarded as one of the broader goals of education. Indeed, much of the literature about teacher authenticity connects it more or less directly with student authenticity (Bonnett and Cuypers 2003; Degenhardt 2003; Brook 2009). Kreber claims that 'what is ultimately in the important interests of students is their own striving for authenticity' $(2013,45)$. But notice that this reasoning also takes for granted the clear possibility and intrinsic value of being authentic, including for younger students whose identities are still in the process of being formed. ${ }^{15}$ 
A real-life example that was recently brought to wider cultural attention helps to capture the intuition that an authentic teacher makes for a better one. Seymour Bernstein, the subject of a touching 2014 documentary Seymour: An Introduction, was a successful concert pianist who voluntarily relinquished a performance career (the holy grail for most classical musicians) in order to teach piano. In sequence after sequence, we see Bernstein reflecting articulately on the meaning of art and gently coaxing out the talent in his students. His authenticity as a teacher seems to be verified by his apparent sacrifice of a more prestigious career, while his abilities as a teacher are attested to by his devoted students. When asked by a former student what he thinks about the artist's obligation to perfect his art, Bernstein replies, 'I poured it into you.'

Bernstein's obvious passion and gift for teaching as an outgrowth of his musical talent give succor to the reassuring assumption that teachers should be authentic. But as I will argue later, there are plenty of counterexamples as well.

These presumed connections between teacher authenticity and effective teaching are sometimes implicit in the education literature, but tend not to be supported by any analysis of what it means to be authentic qua teacher. A brief survey of the literature on authentic teaching shows how easily authenticity can be confounded with other ethical concepts. Crucially, the pedagogy that is thought to amount to good teaching is repeatedly derived from the teacher's personal authenticity, without explaining how one necessarily leads to the other.

\section{Accounts of teacher authenticity}

There are multiple accounts of teacher authenticity in the education literature. Interestingly, they deal mostly with higher education and the authenticity of professors, although there seems to be at least as much of an expectation that teachers of schoolaged children will be authentic. As a rule, the accounts fail either to define personal authenticity as a distinct phenomenon, or to persuasively connect it with teaching, or both. As a result, the arguments in favor of teacher authenticity tend to threaten circularity or rest on unexamined assertions.

The most exhaustive studies of authenticity in teaching have been conducted by Carolin Kreber and her colleagues, blending empirical evidence from university lecturers and students with philosophical conceptions derived from the literature (Kreber et al. 2007; Kreber 2010a, 2010b; Kreber, McCune, and Klampfleitner 2010; Kreber and Klampfleitner 2012, 2013). Uniquely in this body of literature, Kreber et al. have mapped lay people's conceptions of authenticity in (university) teaching onto a variety of philosophical paradigms, which they further elucidate through 13 distinct features (such as 'consistency between values and actions' and 'practicing a constructive developmental pedagogy'), and tested the strength of the association between each feature of authenticity and the perception of effective teaching (Kreber 2010b, 177-178). Importantly, they do not offer an argument for how the general notion of authenticity derived from the philosophical literature can be translated into particular conceptions of authenticity in teaching. While the researchers themselves decline to endorse any particular definition of authenticity, attempting to honor diverse and even contradictory accounts, ${ }^{16}$ they note interesting mismatches between popular conceptions and more philosophical ones. For example, they note that 'the formal dimensions of authenticity ... which relate most strongly to the existential and critical perspectives, feature the least strongly in lay people's conceptions of authenticity in teaching, and were also not closely associated with teaching effectiveness' (Kreber and Klampfleitner 2013, 483; original italics). 
Respondents associated authenticity in teaching with 'being sincere, candid, or honest ${ }^{17}$ and with 'care for the subject, students, and interest in engaging students with the subject around ideas that matter' (Kreber and Klampfleitner 2013, 479). Neither of these dispositions necessarily reveals fidelity to the true self, or even viewing teaching as part of one's identity. At the same time, some of the findings corroborate the reasons I put forward for thinking that an authentic teacher might be a better teacher: associations were found between authenticity in teaching and 'caring for teaching, caring for students and availability' as well as 'interest in, commitment to and enthusiasm for subject and desired effect on students' (Kreber and Klampfleitner 2013, 474). ${ }^{18}$ Students and teachers alike assume, plausibly enough, that authentic teachers will take their jobs seriously. But without an independent conception of authenticity to inform this conclusion, there is reason to worry that they are merely inferring the cause of a perceived effect. In other words, this is not a reason to exhort teachers to be authentic; it would be more direct to simply exhort them to take their jobs seriously.

Indeed, Kreber et al.'s findings repeatedly suggest a conceptual conflation, on the part of professors and students, between authenticity in teaching and teaching effectiveness, especially where the latter is construed along the lines of constructive developmental pedagogy, which emphasizes creating conditions for the students to construct their own learning (Baxter-Magolda 1999). It is often taken for granted that teachers who make students feel supported in their learning are de facto authentic teachers. The researchers do not seem deterred by these findings, however, urging further statistical analysis based on 'all those constructs that ... were deemed most meaningful in the eyes of most respondents' (Kreber and Klampfleitner 2013, 485). Empirically, this may provide interesting information about lay people's conceptions of authenticity in teaching, but it would not advance the more challenging philosophical work of clarifying teacher authenticity. Without a convincing analysis of what authenticity in teaching ought to mean and why it is valuable, attainable, and distinct from other virtues, relying on qualitative data may just be perpetuating fuzzy ideas and engaging in circular reasoning.

Another team of researchers, Cranton and Carusetta, have taken a stance on the meaning of authenticity in teaching based on their own, rather than test subjects' perceptions. They suggest that there are four components of authenticity, all of which are relevant to teaching. They are: 'being genuine, showing consistency between values and actions, relating to others in such a way as to encourage their authenticity, and living a critical life' (Cranton and Carusetta 2004, 7). While these may all be noble ways of being a teacher and of living more generally, they also blend categories and leap to conclusions. ${ }^{19}$

On the first criterion, Cranton and Carusetta express the importance of 'speaking genuinely and honestly rather than with an intent to manipulate or deceive' (Cranton and Carusetta 2004, 7). This criterion is equivalent to what I earlier called 'sincerity.' Why should we think that teachers who 'speak genuinely and honestly' must be authentic? If they force themselves to do this, against their natural inclination, are they still authentic? It seems that authenticity is not actually the target of this criterion. Moreover, we could probably imagine situations in which dishonesty or deception might be more ethical and more educational than unqualified sincerity; I present an example of this in the next section.

The second aspect of authenticity mentioned is consistency, which implies convergence between two aspects of the same person - namely, her words and her behavior. The pitfall to be avoided here is hypocrisy; as Cranton and Carusetta put it, 'educators should practice what they preach and be sure not to espouse one way of working and then behave in a different way in their own teaching' (Cranton and Carusetta 2004, 7). 
However, hypocrisy is not the same as inauthenticity nor is consistency the same as authenticity. Aiming to be consistent across behaviors defers answering the question of who one really is and hence which behaviors are actually expressive of one's true self. An individual could in principle be consistently inauthentic.

The third of Cranton and Carusetta's criteria for authenticity is encouraging authenticity in others. Following Freire, the authors argue that dialog is central to learning and that learning is enhanced when both the teacher and the students can be 'transformed' through the process (Cranton and Carusetta 2004, 8). This conception of teaching shares with some conceptions of authenticity a vision of identity formation through the pursuit of communal ideals (e.g. Taylor 1991; Varga 2012). But it is circular to contend that being authentic is reducible to nurturing authenticity in others. This formulation would need to be substantiated by some further description of the self that is doing the nurturing or being nurtured, or a way of recognizing when others have become authentic.

More generally, defining authenticity in terms of obligations to others or ethical duties of any kind risks confusing the value of authenticity with morality more generally, as we saw with Taylor. In the work of Cranton and Carusetta and others, being an authentic teacher is sometimes mistaken for being a moral teacher, period. Grimmett and Neufeld repeatedly assert this overlap without defining either 'authenticity' or 'morality' independently (Grimmett and Neufeld 1994, 4-5, 208, 216).

The final aspect of authenticity delineated by Cranton and Carusetta is alternately described as 'living a critical life' and 'reflective learning' and can involve '[questioning] how we are different from the community,' avoiding 'repetitive and ritualistic' performance, and '[being] bold, [daring] to take risks' (Cranton and Carusetta 2004, 80). A number of ideas are folded into this criterion, from critical thought to non-conformity, creativity, and innovation. All these may have something to do with authenticity, but it would depend on the self in question. Being your true self may or may not result in standing out or being on the cutting edge of pedagogy. A true self could just as easily be quiet, risk-averse, and conformist.

There are other versions of teacher authenticity in the literature, ${ }^{20}$ but the ones surveyed here suggest some concerning trends. All the traits and habits attributed to authentic teachers on these accounts may be described in other, often less nebulous, terms. They typically sidestep the identity puzzles that arise in philosophical discussions of authenticity, and even when they appeal to the philosophical literature, as Kreber et al. do, there is little consternation over the unrigorous application of these concepts to general educational discourse. The normative presumption in favor of teacher authenticity is so strong that educational scholars seem to have given up on analyzing personal authenticity separately from good teaching.

\section{Test cases: Nuancing the relationship between authenticity and good teaching}

None of this is to make the claim that authenticity is bad for teaching, nor the more dismissive claim that authenticity and teaching are unrelated. Insofar as we can say that there is something like a true self, it may be preferable to have teachers for whom teaching is an essential expression of such a self. Yet, there may be other, equally compelling reasons for us to question the value of teacher authenticity. I will consider three examples of teachers (one real, two fictional) who challenge some of our assumptions about the meaning and value of authenticity in teaching in order to show that the relationship may actually be quite complicated. 
First, consider the case of Jim Keegstra, the Canadian teacher who was convicted of hate speech in 1984 after preaching anti-semitism and Holocaust denial to his high school students (Hare 1996). It would seem that he harbored his racist views entirely authentically, on any conception of the term: they were part of his identity, impervious to counterevidence, a character trait that he could not or would not overcome. Moreover, it is equally possible that he felt that teaching was part of his identity; indeed, he may have felt himself morally obliged to use public education as the platform for actualizing his perceived calling in life. ${ }^{21}$ Indoctrinating his students into his racist views therefore may have constituted an expression of his true self. The Keegstra case demonstrates that not only is authenticity an insufficient condition for both morality and good teaching, but also that having an authentic teacher may be disastrous for students. Why be true to oneself if one's true self is a villain?

This case poses a direct challenge to the defenders of a virtue conception of authenticity, including followers of Taylor, who stipulate that authentic teachers are ethical teachers. They would have to deny that Keegstra is authentic, despite compelling evidence to the contrary, perhaps insisting that an authentic teacher always has her students' best interests in mind. Yet, would Keegstra not say that this was precisely his motivation? Did he not feel that he had an important truth to reveal, which had been explicitly repressed, and which it was his duty to impart to his students (much, I might add, as many social justice educators do)? The virtue defenders could say, then, that they advocate teachers committing themselves to causes that are viewed as positive by everyone. But then it is unclear that what we are talking about is authenticity. An immoral person could be an authentic teacher, or else there is no independent content to the notion of 'authenticity.' Likewise, an excellent teacher could be inauthentic. Mr. Holland, the protagonist of the 1995 feel-good film Mr Holland's Opus, is a musician-composer who takes a job teaching high school music to make ends meet. It is made clear in the setup of the film that Mr. Holland does not feel this career path to be an expression of his true identity when he first embarks on it. He would be more authentic if he pursued his lifelong dream of being a composer, irrespective of the practical consequences. He initially feels out of place as a teacher; he does not feel he is following his deepest desires or his 'calling;' he needs to force himself into this posture. Yet, in spite of - or perhaps because of - his sense of being an outsider, Mr. Holland turns out to be a gifted teacher, finding creative ways to inspire students in the drab educational infrastructure of 1960s' America.

Of course, an important upshot of the film is that Mr. Holland's identity evolves over the course of several decades, and the inauthenticity that he feels so acutely at the beginning of his career appears to dissipate entirely. This evolution, which is plausible if also contrived for dramatic effect, takes seriously the importance of change and temporality in the construction of selfhood (Ricoeur 1992). Yet, it also clings to the intuitive notion that some aspects of ourselves are simply given, whether we are in a position to recognize them or not. The conceit of the story is that Mr. Holland turns out to be an 'authentic teacher' at heart, and he lives his dream of being a composer via the teaching career that he initially resisted.

But is this a victory for advocates of teacher authenticity? If Mr. Holland had been goaded into being authentic at the beginning of the film - perhaps by trying to make it as a composer - he likely never would have entered teaching in the first place. His success at teaching, at least initially, appears to have been attributable more to his inauthenticity as a teacher than to any authenticity. This does not speak well in favor of choosing authentic teachers over inauthentic ones. 
A final example will add further texture to these distinctions. In the poignant film Monsieur Lazhar, an Algerian refugee fills in after a fifth-grade class discovers their teacher has committed suicide. Monsieur Lazhar claims that he had been a headmaster in Algeria, but throughout the film a different - and more traumatic - history emerges. He is not authentic in the minimal sense of being a 'real' (certified) teacher. While his deceased wife had been a teacher, Monsieur Lazhar himself was a small restaurateur. In a more profound sense, however, Monsieur Lazhar demonstrates himself to be a natural teacher who not only connects with his traumatized students, but crucially, honors his identity and the memory of his murdered family through the act of teaching. Ironically, he only gains access to the classroom by deliberating lying about his credentials and repeatedly dodging students' and colleagues' questions about his background. Contrary to the intuitions of most of Kreber et al.'s subjects, his authenticity has nothing to do with candidness or honesty. Monsieur Lazhar's insincerity is actually a necessary condition of his authenticity. His authenticity, in turn, is related to his excellence at teaching, but only because of who he happens to be: teaching, and teaching these particular students, is a necessary therapeutic process for him. Throughout the film, Monsieur Lazhar's qualities as a teacher are subtly contrasted with those of his predecessor, a young woman who appeared to fulfill all the expectations of a great teacher, but scarred her students by hanging herself in their classroom. The strong implication is that authenticity is not uniformly related to good teaching, as many believe. It all depends on the teacher.

\section{Rethinking teacher authenticity}

It is not surprising that authenticity should be an ideal pursued by educators and valued by educational theorists. Education, like authenticity, is opposed to dissimulation, ignorance, manipulation, and related states of misalignment between truth and selfhood. As a culture, we hold personal authenticity in high esteem - despite its fuzzy borders - and would understandably wish for our children to be educated by those who embody such a virtue. Yet, claims about the value of teacher authenticity are two-part claims about personal authenticity and what it means to be a good teacher, and these types of claims are often confounded. Stripped away from notions of sincerity, normative duties to others, critical inquiry, non-conformity, and a variety of other concepts, authenticity is fundamentally about being true to oneself. Whether that self is one we would want to see expressed in the classroom depends greatly on who the teacher is.

I have sketched a way of thinking about what it means for teachers to be true to themselves qua teachers, but it is not yet obvious that authenticity matters more for teachers than for other individuals. Most of the virtues that describe good teachers can be described without any reference to authenticity. In contrast to most researchers' and lay people's intuitions, authenticity does not seem to necessarily predict good teaching, nor inauthenticity bad teaching, as the three examples show - for who would not prefer an inauthentic Mr. Holland to an authentic Mr. Keegstra? This is not a reason to abandon the notion of teacher authenticity, but it should at least encourage us to take a more rigorous approach to it.

\section{Acknowledgments}

I would like to thank Doron Yosef-Hassidim for his assistance with this research. For feedback on the ideas presented here, I am grateful to Derek Gottlieb, reviewers for this journal, and audiences at the American Educational Research Association, the Philosophy of Education Society of Great Britain, and the Ontario Institute for Studies in Education. 


\section{Disclosure statement}

No potential conflict of interest was reported by the author.

\section{Funding}

This research was supported by a Connaught New Researcher Fellowship from the University of Toronto.

\section{Notes}

1. Kreber, McCune, and Klampfleitner (2010) and Kreber and Klampfleitner (2013) observe this as well, although they decline to defend any particular philosophical conception of authenticity in teaching.

2. Because I am focusing on teacher authenticity, the application of authenticity language to aspects of education other than personal identity will be less important for my purposes. Moreover, as I will argue, grappling with the notion of teacher authenticity is more philosophically urgent and challenging than examining, say, authentic pedagogy or authentic assessment, which do not tend to make problematic claims about the identities of people in the classroom. Indeed, teacher authenticity is vaguely credited with generating all sorts of other forms of authenticity, including student authenticity. I therefore take the normal identity-related concept of authenticity as my starting point and examine how it may or may not correlate to claims about a teacher's overall efficacy or virtue.

3. I have given a more thorough account of this claim and the structure of authenticity, in general, in (Bialystok 2014).

4. Post-structuralists, who tend to reject authenticity talk altogether, may go a step further than the existentialists, claiming that identity is a performance, a negotiation, an interpretation, or a form of experimentation. These types of accounts (e.g. Foucault 1988; Butler 2006) have been popular among some educational theorists. They still require, however, some material and/or psychic starting point that can be a subject of such processes.

5. Indeed, by what standards are the actions to which I devote my authentic self even judged to be virtuous? What if a person 'authentically' devotes herself to an ideological cause that matters to some at the expense of others, such as a fanatical religious sect?

6. Several defenders of the virtue conception of teacher authenticity make a passing acknowledgment of this counterexample, and then go on to reiterate the virtue account without further argument. See Chickering, Dalton, and Stamm (2006, 8); Kreber (2013, 18); and Cranton $(2006,83)$. I return to this problem in the final section.

7. Elsewhere, I have made a more thorough case for regarding gender identity as an aspect of the self that can also be dealt with authentically or inauthentically (Bialystok 2013).

8. Teacher authenticity is sometimes reduced to a function of teachers' relations with students (e.g. Brookfield 2006; Frego 2006). While the self can never be fulsomely described in solipsistic terms, reducing authenticity to relationality seems to trivialize what is compelling about personal identity. Relationality already presumes that there are individuals with an irreducible experience of interiority, who stand to affect and be affected by interactions with others.

9. I am not suggesting that Kreber was not authentic by coming out in her work place, but that sincerity and authenticity may have accidently converged in this case: telling others who she was proved necessary for Kreber's sense of having an authentic relation to herself.

10. For an excellent critique of some of the uses of authenticity in education, see Petraglia (1998).

11. It is far from clear that these types of educational trends track something we would recognize as authenticity in a philosophical sense (again, see Petraglia 1998), but I leave that aside for the purposes of this paper.

12. Teacher authenticity has also been connected to practices outside the classroom, such as 'critical reflection' (Brookfield 1995; Dirkx 2006) and 'soul work' (Palmer 1998; Dirkx 2006) or 'spirituality' (Chickering, Dalton, and Stamm 2006). While introspective practices hold out the promise of revealing something about a teacher's identity, possibly providing her with insights into herself that may inform her teaching, the recourse to unsubstantiated 
depth language (the 'teacher within,' the 'inner voice'), and its concomitant recreation of an 'aura' of authenticity, invites the same scathing critique of authenticity that Adorno ([1964] 1973) leveled against his contemporaries decades ago.

13. Kreber concurs: 'I want teaching to be an important aspect of what I do because it is part of who I am. It is part of my identity' (Kreber 2013, 23).

14. Appealing to Heidegger, Kreber et al. (2007) link authenticity in teaching to the process by which an individual becomes a teacher. If it was an authentic choice, the teacher may be said to be an authentic teacher. Brook (2009) makes a similar, though more opaque, argument.

15. Haji and Cuypers (2008) explain the potential paradox of teaching for authenticity since education itself is always already a form of manipulation.

16. For example, they give equal weight to the Heideggerian version of authenticity (Heidegger 1996) and Adorno's famous critique of ([1964] 1973), without attempting to adjudicate between these incompatible perspectives (Kreber and Klampfleitner 2013, 466).

17. Mary Warnock, a philosopher of education, also argues that 'the first rule of teaching is sincerity, even if one's sincerity is dotty or eccentric' (Warnock 1996, 185). She does not, however, insinuate that teacher sincerity guarantees (or reflects) either personal authenticity or high-quality teaching.

18. Subjects in Vannini's empirical work also agreed that 'the most authentic component of teaching is the possibility to be useful to students' $(2006,250)$.

19. This work is especially important to critique because it is widely cited by other educational theorists. For example, Cranton's edited volume Authenticity in Teaching (2006) contains essays by seven other authors, most of whom reproduce her and Carusetta's version of authenticity uncritically.

20. E.g. Brookfield $(2006,5)$. As I have indicated throughout this paper, the critiques of Kreber and Cranton and Carusetta are generalizable to a large number of educational writers.

21. Sincerity and authenticity must be carefully disentangled in this case. Certainly, the primary crime Keegstra committed was imposing his views on his students, which does not automatically attest to the authenticity of his views (although it is hard to imagine why else he would disseminate them). Yet, it would not suffice to suggest that Keegstra ought to have been merely insincere, denying his hateful views on the job while harboring them privately. This is a person whom we might wish to simply remain inauthentic.

\section{References}

Adorno, Theodor. [1964] 1973. The Jargon of Authenticity. Translated by Knut Tarnowski and Frederic Will. Evanston, IL: Northwestern University Press.

Ashton, Sam. 2010. "Authenticity in Adult Learning." International Journal of Lifelong Education 29 (1): 3-19.

Baxter-Magolda, Marcia. 1999. Creating Contexts for Learning and Self-authorship: Constructive Developmental Pedagogy. Nashville, TN: Vanderbilt University Press.

Bialystok, Lauren. 2011. "Refuting Polonius: Sincerity, Authenticity, and 'Shtick'." Philosophical Papers 40 (2): 207-231.

Bialystok, Lauren. 2013. “Authenticity and Trans Identity.”In Talk About Sex: A Multidisciplinary Discussion, edited by Scott Stewart, 122-145. Sydney, Nova Scotia: Cape Breton University Press.

Bialystok, Lauren. 2014. "Authenticity and the Limits of Philosophy." Dialogue 53 (2): 271-298.

Bonnett, Michael. 1978. "Authenticity and Education." Journal of Philosophy of Education 12: 51-61.

Bonnett, Michael, and Stefaan Cuypers. 2003. "Autonomy and Authenticity in Education." In The Blackwell Guide to the Philosophy of Education, edited by N. Blake, P. Smeyers, R. Smith, and P. Standish, 326-340. Oxford: Blackwell.

Brook, Angus. 2009. "The Potentiality of Authenticity in Becoming a Teacher." Educational Philosophy and Theory 41 (1): 46-59.

Brookfield, Stephen D. 1995. Becoming a Critically Reflective Teacher. San Francisco, CA: Jossey-Bass.

Brookfield, Stephen D. 2006. "Authenticity and Power." New Directions for Adult and Continuing Education 2006: 5-16. 
Buchmann, Margret. 1993. "Role over Person: Morality and Authenticity in Teaching." In Detachment and Concern: Conversations in the Philosophy of Teaching and Teacher Education, edited by M. Buchmann and R. Floden, 145-157. London: Cassell.

Butler, Judith. 2006. Gender Trouble: Feminism and the Subversion of Identity. New York: Routledge.

Chickering, Arthur W., Jon C. Dalton, and Liesa Stamm. 2006. Encouraging Authenticity and Spirituality in Higher Education. San Francisco, CA: Jossey-Bass.

Cottingham, John. 2010. "Integrity and Fragmentation." Journal of Applied Philosophy 27 (1): $2-14$.

Cranton, Patricia. 2001. Becoming an Authentic Teacher in Higher Education. Malabar, FL: Krieger.

Cranton, Patricia. 2006. "Integrating Perspectives on Authenticity." New Directions for Adult and Continuing Education 2006: 83-87.

Cranton, Patricia, and Ellen Carusetta. 2004. "Perspectives on Authenticity in Teaching." Adult Education Quarterly 55 (1): 5-22.

Degenhardt, M. A. B. 2003. "Should Philosophy Express the Self?" Journal of Philosophy of Education 37 (1): 35-51.

Dirkx, John M. 2006. "Authenticity and Imagination.” New Directions for Adult and Continuing Education 2006: 27-39.

Foucault, Michel. 1988. Technologies of the Self: A Seminar with Michel Foucault. Edited by Luther H. Martin, Huck Gutman, and Patrick H. Hutton. Amherst: University of Massachusetts Press.

Frankfurt, Harry. 1988. The Importance of What We Care About. Cambridge: Cambridge University Press.

Frego, Katherine. 2006. "Authenticity and Relationships with Students." New Directions for Adult and Continuing Education 2006: 41-50.

Grimmett, Peter, and Jonathan Neufeld, eds. 1994. Teacher Development and the Struggle for Authenticity. New York: Teacher College Press.

Guignon, Charles. 2004. On Being Authentic. London: Routledge.

Haji, Ishtiyaque, and Stefaan Cuypers. 2008. Moral Responsibility, Authenticity and Education. New York: Routledge.

Hare, William. 1996. "Propaganda in the Classroom: The Keegstra Case." In Philosophy of Education: Introductory Readings. 2nd ed., edited by William Hare and John Portelli, 149-164. Calgary: Detselig.

Heidegger, Martin. 1996. Being and Time. Translated by Joan Stambaugh. Albany: SUNY Press.

Kreber, Carolin. 2010a. "Courage and Compassion in the Striving for Authenticity: States of Complacency, Compliance, and Contestation.” Adult Education Quarterly 60 (2): 177-198.

Kreber, Carolin. 2010b. "Academics' Teacher Identities, Authenticity and Pedagogy." Studies in Higher Education 35 (2): 171-194.

Kreber, Carolin. 2013. Authenticity in and through Teaching in Higher Education: The Transformative Potential of the Scholarship of Teaching. London: Routledge.

Kreber, Carolin, and Monika Klampfleitner. 2012. "Construing the Meaning of Authenticity in University Teaching: Comparing Explicit to Implicit Theories." Journal of Constructivist Psychology 25 (1): 34-69.

Kreber, Carolin, and Monika Klampfleitner. 2013. "Lecturers' and Students' Conceptions of Authenticity in Teaching and Actual Teacher Actions and Attributes Students Perceive as Helpful." Higher Education 66 (4): 463-487.

Kreber, Carolin, Monika Klampfleitner, Velda McCune, Sian Bayne, and Miesbeth Knottenbelt. 2007. "What Do You Mean by Authentic? A Comparative Review of the Literature on Conceptions of Authenticity in Teaching." Adult Education Quarterly 58 (1): 22-43.

Kreber, Carolin, Velda McCune, and Monika Klampfleitner. 2010. "Formal and Implicit Conceptions of Authenticity in Teaching." Teaching in Higher Education 15 (4): 383-397.

Martel, Angeline. 1989. To Pedagogy and What Matters: Texts on Authenticity. Alberta: Faculty of Education, University of Alberta.

Newmann, Fred, Helen Marks, and Adam Gamoran. 1996. "Authentic Pedagogy and Student Performance." American Journal of Education 104 (4): 280-312.

Palmer, Parker. 1998. The Courage to Teach: Exploring the Inner Landscape of a Teacher's Life. San Francisco, CA: Jossey-Bass. 
Petraglia, Joseph. 1998. Reality by Design: The Rhetoric and Technology of Authenticity in Education. Mahwah, NJ: Lawrence Erlbaum.

Ricoeur, Paul. 1992. Oneself as Another. Translated by Kathleen Blamey. Chicago, IL: University of Chicago Press.

Splitter, Laurance J. 2009. "Authenticity and Constructivism in Education." Studies in Philosophy and Education 28 (2): 135-151.

Taylor, Charles. 1991. The Ethics of Authenticity. Cambridge, MA: Harvard University Press.

Trilling, Lionel. 1972. Sincerity and Authenticity. Cambridge, MA: Harvard University Press.

Vannini, Phillip. 2006. 'Dead Poets' Society: Teaching, Publish-or-Perish, and Professors' Experiences of Authenticity." Symbolic Interaction 29 (2): 235-257.

Varga, Somogy. 2012. Authenticity as an Ethical Ideal. New York: Routledge.

Velleman, David. 2006. Self to Self: Selected Essays. Cambridge: Cambridge University Press.

Warnock, Mary. 1996. "The Neutral Teacher." In Philosophy of Education: Introductory Readings. 2nd ed., edited by William Hare and John Portelli, 139-148. Calgary: Detselig.

Williams, Bernard. 2002. Truth and Truthfulness. Princeton, NJ: Princeton University Press. 